\title{
Rethinking the Role of the Military in the Modernisation of the Nigerian Local Government System
}

\author{
Daniel Adetoritse Tonwe, Ph.D. \\ Senior Lecturer, Department of Political Science and Public Administration, \\ University of Benin, Benin City, Nigeria. \\ Tel: 08028427001, email: datonwe@yahoo.com
}

Eddy Akpomera, Ph.D.

Faculty Officer, Faculty of Social Sciences, University of Benin, Benin City, Nigeria. Tel: 08033485535, email: eddyakpomera@yahoo.com

Doi:10.5901/mjss.2013.v4n13p153

\begin{abstract}
In the developed countries, the military is identified largely for their role in the defence of the country from external aggression and helping out with internal security when the need arises. On the contrary, in a number of developing countries of Africa, Asia and Latin America, when the military is mentioned, their traditional defence and internal security functions get obscured in their political role. For a thirty-year period (1966 - 1999), Nigeria was in this category of countries where the military have combined their constitutional role of defence of the country with that of political governance. While the participation of the military in governance has substantially fizzled out world wide, their impact on the socio-economic and political evolution of the countries concerned have been enormous. This paper critically examines the local government system in Nigeria midwifed by the military in the three decades of their rule; the initial emphasis on efficiency-oriented administration at the local level, the effort which culminated in the 1976 local government reform and the issue of whether the military can serve as modernizers in developing countries.
\end{abstract}

Keywords: Local government, military, modernization, democracy, efficiency - oriented administration.

\section{Introduction}

In many countries, particularly the developed ones, the military is confined to defence from external aggression and sometimes the internal security of the country when the need arises. On the contrary, in a number of developing countries of Africa, Asia and Latin America, when the military is mentioned, their defence and internal security functions get obscured in their political role. A major factor that fueled Africa's post-colonial developmental crisis has been the absence of good and democratic governance among its member states. A major reason for this absence has been the inappropriate and counter-productive involvement of the military in governance in the continent. To examine the military as an institutional actor in politics, democracy and, ultimately, governance would not be axiomatic in analyses of major Western democracies. But to omit the role of the military from this subject in some African states would constitute a significant oversight. Until just over a decade ago, in parts of Africa, the military, as an institution of the state were active actors in politics and governance although it lacks legitimacy as an agent of good and democratic governance. While the institutional footing of the military in Africa is fast disappearing, the impacts of the long autocratic regimes are still very much evident. Nigeria falls into this category of countries where the military have combined their traditional role of defence of the country and that of governance. The socio-economic and political evolution of Nigeria have been shaped more by the military regimes than civilian governments because the military has been in power in the country for more than half of the period since independence. This paper examines the role of the military in shaping the local government system in Nigeria for three decades and impact they have made in the sector.

\section{Military Intervention in Nigeria: The background}

When Nigeria gained Independence in 1960, it was thought most unlikely that the military would have any role in the 
governance of the country, not to talk of playing a dominant role in her politics. For one thing, it was most unexpected that the political elites both at the national and regional levels, supported by well established political parties, whose branches could be found in practically every sizable town, would be challenged by the armed forces that have been left behind by the Colonial Administration. The military at independence was small in number, defective in equipment, with few experienced indigenous officers, having little prestige and generally looked down upon by the citizenry that are politically conscious because of their role in perpetuating colonial rule. The smallness of the Nigerian Army was particularly glaring. The Nigerian Armed Forces numbered only 7,500 at independence and the estimated population of the country during this period was $45,000,000$ (Miner, 1971). In contrast, a country like Argentina with half Nigeria's population had an army of 120,000 during this period.

All these might have seemed to be discernible logical reasons why military intervention was not to be anticipated in Nigeria in the first few years immediately following Independence. However, the factors listed above which made the disruption of the democratic process in Nigeria unlikely did not remain unchanged as the years rolled by. The Army was enlarged, either for reasons of prestige or because a large army was required to take care of any threat of external aggretion and to ensure internal security. New officers were rapidly trained and promoted to fill the vacuum created by expatriates who had to leave the service during the period of terminal Independence and immediately after the country gained Independence (Ademoyega 1981; Siollun 2009).

The image and prestige of the army was given a boost by the rapid decline in the prestige of politicians due to corrupt practices and the break-down of law and order. The fact that the army was insulated from politics made them faultless from the negative developments that were taking place in the country as far as the public was concerned. Taking advantage of the growing discontentment of the masses with the politicians, the army orchestrated a military coup on 15 January 1966 to stall civil rule in Nigeria. A number of key political leaders were assassinated in Lagos, Ibadan and Kaduna. Speaking on Radio Kaduna just after noon that Saturday, 15 January, Major C. Kaduna Nzeogwu, who led the coup in the city, declared martial law over Northern Nigeria in the name of the Supreme Council of the Revolution decreed the suspension of the constitution and the dissolution of the Regional Governments and the elected Houses of Assembly. Nzeogwu remained in control in Kaduna till Tuesday, 18 January, when he accepted the authority of the head of the army, Major-General Aguiyi Ironsi (Fist, 1970).

Once formally installed, the Head of the Military Government, General Ironsi, backed by the military chain of command, decreed that the Federal Military Government has supreme authority of the country. He replaced hitherto legitimate regional authority with the Military Governor, proscribed political party activities and started on a course of unifying the public services and the judicial services. With the proscription of political activities, not only did the Federal Parliament and the regional assemblies automatically stood dissolve, but the various Local Governments also ended their existence. Local government affairs came to be directed by appointed rather than elected people. The coming to power of the military government was hence significant not only at the national and regional levels, but also at the local government level.

\section{Aims of Military Leaders for Local Government in the First Decade}

What objectives did the government military elites conceive for local government in the first decade (1966 to 1975) of governance? From the outset, the aims set by the military leaders for local government are probably more important in this era than the aims set by the colonial bureaucratic elite in the colonial era or by the struggling political elites, wrestling with a new democratic system of government and opposition. This is because though local government in all these periods remained the creation of the central government (the colonial administration in the colonial era, the regional government in the self-governing period), with the military administration, more direct control in accordance with military tradition was exercised over local government. The strict hierarchical structure and organisation of the military made flexibility in the implementation of objectives less common, and tighter control from the centre was more the practice in this era. During this period, there was a high degree of rigidity and inflexibility in keeping with military practices both at the regional (and later, with the creation of states, at the state) level as well as at the local government level. Also, there was a situation in which some of the general objectives for local government were laid down by the federal government, a practice which in the era of the politicians might have been frowned upon as an encroachment by the federal government, since local government was a constituted responsibility of the regional government. By the suspension of the constitution, the relationship between the three levels of government, namely the federal, state and local governments became much fused. This was made clear by General Gowon, the then military Head of State when he stated that: 


\begin{abstract}
We are now at the threshold of what could be a great decade of faster development and modernization. The government is very conscious of the needs and aspirations of the ordinary man for peace and security, a rising standard of living and better opportunities for his children. These are the thing which matter, the challenge before every government... be it local, regional...or the federal government (Gowon, 1970:2-3).
\end{abstract}

For the military, the challenge before every level of government was the same - that of fast economic development and a modernization of the way of living. This was to mean a rise in the standard of living and the establishment, after a three-year-long civil war, of a lasting peace, security and better opportunities for posterity. The prescribed authorities in the states also stated similar objectives or took actions that confirmed a belief in and acceptances of the ideal. In February 1966 for example, the Military Governor for Northern Nigeria, Lieutenant-Colonel Hassan Katsina, announced that native courts were to be brought under the control of the Chief Justice of the Federation, the Native Authority police forces were also to come under the operational control of the Inspector-General of the Nigerian Police (the federal government maintained police force). The local authority prisons, he announced, were also to be handed over to the federal government (Summerhayes, 1969). Hence most of the law and order functions that had been of the topmost priority in the colonial era and which had sapped the energy, attention and finances of the local authorities in the self-governing era were given up to the federal government. By the transference of these law and order functions from the local governments to the macro governments, the local governments could then work in accordance with the priority of the military administration, which in effect was to provide the services as cheaply and quickly (efficiently) as possible. In this spirit of efficiency, local governments were thus encouraged to concentrate their attention on service rather than protective or coercive functions as in the past. Thus social services, development of resources rather than protective or coercive functions (as in the colonial period) took precedence.

Efficiency oriented administration was the major objective of the military administration during this period. The trend was the setting up of efficient rather than democratic administration. The objective of the local councils was to usher in quick development as against nurturing a participative or democratic body. In the operation of these councils, the regime's preference for efficiency rather than democracy was apparent (Orewa \& Adewumi, 2003).

What seems implicit in the aims and objectives of the military elites for local government is their utter neglect of the democratic ideal and political participation. This is not too surprising. The military took over power by force and intended to run the affairs of state in a purely military style, i.e. through a kind of military chain of command. Laws, orders and legislations were made through the use of edicts in the states and the promulgation of decrees by the central government. The question of popular participation was completely ruled out (Odetola, 1982). The absence of these ideals constituted a grave defect in the functioning and running of local government. If, local government is to help foster local democracy and participation and to inculcate political education as well as provide a forum as a nursery for feeding the upper levels of government, then the absence of the ideal constitutes a grave departure for the development of democratic local government in the country. During this era, there was a noticeable and notoriously apathetic attitude on the side of the federal government to the local governments. Local government, whatever its conditions and plight, was left in the hands of the state governments. There was no concerted effort on the part of the federal government to place any priority or respectable emphasis on local government. The attitudes and actions of the state governments, on the other hand, were in this era rather dispersed and uncoordinated, and in some states, unusually novel and independent efforts at varying reforms were made (Ola, 1984).

\title{
4. Appraisal of the Development of Local Government in the First Decade of the Military (1966-1976)
}

One distinctive characteristic of government in this military era was its fused and undifferentiated structure. A very hazy dividing line existed between the authority and jurisdiction of the federal military government and the regional (later state) governments. Even hazier was the dividing line between the jurisdiction and authority of the state government and the local government. If the objective of local government is simply to supply services, then the maximum possible centralisation may be an acceptable answer. If however the object is to increase local participation in government and make services more responsive to local feelings, then the standard of the services may often suffer (WAM, 1971).

This overemphasis on efficiency and on the provision of services at the expense of participation of the people and at the expense of democratic ideals that had started to grow in the self-governing era (ideals of freedom, equality and tolerance) was partly responsible for the inadequacies in local government performances in this era. Having once given the people a chance to taste of the benefits of self-rule at the local level, it would seem like turning back the hands of the clock to find central government officials taking over affairs for which elected councillors had previously been responsible.

The military being a totalitarian regime, probably perceived local government or any form of decentralized authority 
as a possible source of confrontation with their own power (Wit, 1961). When, however, a totalitarian regime is compelled to compromise or when it decides in its own grace to make some concessions and to grow into a modernizing autocracy, certain characteristics become evident in it. These are strict hierarchy of authority; exclusivism; strategic flexibility; and unitarism.

A regime that is responsible to the people's demands would always endeavour to take good care of two basic. The first is to provide for machinery which will accommodate local pressures and the intense politics they generate and provide access to the local populace (Lockard, 1968). The second is that the regime will endeavour to make provision for posts of leadership which can defend local interest (Humes, 1973). During this era, local government did not provide the machinery necessary to accommodate local pressures and local politics. The people were unable to associate with those hand-picked, on several accasions from outside the locality, and so it did not provide access to the local population. Local government was not in a position to encourage the growth of local leadership, since select citizens were required to manage the local governments apart from the career administrative officials.

In effect, the so called emphasis on economic progress and provision of services was at the expense of political participation and unchecked prevalence of bribery and corruption at local government level.

\section{The Great Local Government Reform Decree of 1976}

Before the Gowon's administration was toppled on July 29, 1975, a Public Service Reform Commission had been set up and its term of reference was the entire civil service in the country. The sphere of local government was one of the several areas the Commission was expected to investigate and report upon. The Commission adopted the strategy of working through select study groups. In the sphere of local government, the Commission made recommendations which were accepted by the federal government. In line with the acceptance of these recommendations by the Federal Government, the State Governments set up committees to recommend the financial and functional relationships that should exist between the State Governments and Local Government. By July 29, 1975 when the Gowon administration was toppled in a counter military coup, most of these committees were yet to commence sitting.

The new regime under General Murtala Mohammed, who had his programme continued under General Obasanjo on the former's assassination decided not to disturb the committees already set up by the State Governments. This caution on the part of military was remarkable considering the fact that Local Government Reform was one of the administration's cardinal programmes, in fact the second in the order of priority directed towards returning the country to civil rule in 1979. Rather, the Federal Military Government decided to set up a political division in the Federal Cabinet Office in Lagos to which the reports of the State Governments were to be referred for scrutiny. The reform exercise was open to the most comprehensive consideration of all vital factors and extensive consultation with all knowledgeable and interested parties. On the whole, the efforts of various working groups consisting of local government practitioners and consultants both at the Federal and State levels, inputs from local notables and the Public Service Review Committee Report culminated in a policy output in the shape of 1976 Federal Republic of Nigeria Guidelines for Local Government Reform.

1976 witnessed a fundamental breakthrough in the reform process of local government in Nigeria. The 1976 Guidelines for Local Government Reforms were specifically aimed at putting government at the local level on a sound footing in all the States of the Federation. One of the cardinal areas of emphasis of the Reform was in regard to the status of local government in the country. There has been no doubt about the existence of local government in the country. The Federal Military Government has therefore decided to recognise local governments as the third tier of governmental activity in the nation. Local government should do precisely what the word government implies, i.e. governing at the grassroots or local level (Guideline for Local Government Reform 1976). This statement marked the unequivocal beginning of a tripartite political arrangement in the country.

The functional relationship between the three levels of government, particularly between the State and Local Government before 1976 was much fused. The Reform greatly remedied the situation by making very clear the jurisdiction of local governments as well as other areas where both the State government and local governments have concurrent jurisdiction. This was done by categorizing local government functions into two. The first category consists of items which are local in nature and which are to be considered as the exclusive responsibility of local governments, save in exceptional or temporary circumstances. The second category consists of items which are to be regarded generally as local government functions, but which could be jointly performed by local governments, state governments or other agencies in the area or solely by state governments or other agencies until such a time when local governments are in a position to perform such functions. 
Dearth of finance had always been one of the major handicaps that hinder local governments in the performance of their functions in the country. The 1976 Reform contained far reaching provisions in the sphere of local government finance. The document declared certain sources of revenue as the exclusive preserves of Local Government. In addition, the State and Federal Governments were required to make contributions to augment the finances of local governments. It is note worthy that for the first time in the history of local government in Nigeria; the Federal Government was made to shoulder part of the responsibilities in the sphere of local government financing. Accordingly, the Federal Government started grant-aiding local governments to ensure that they are financially viable to shoulder their new responsibilities. To enable the new local governments perform their new responsibilities without being weighed down by their back-log of debts, the 1976 Reform documents required the state governments to cancel all debts owned to them by local governments.

Before the 1976 Local Government Reform, there was a great deal of difference in the structural arrangements in the sphere of local government in the country. In contrast, informed by the need for uniformity, the 1976 Reform introduced, throughout the length and breadth of the country, a single tier multipurpose local government structure. The populations of the new local government units were also streamlined.

The question as to what should be the proper place of traditional rulers in government at the local level in the light of their dwindling role has always been an issue in the local government set-up. This was made very clear in the 1976 Guidelines for Local Governments Reform. The Reform document placed traditional rulers above partism politics and stipulated that any traditional office holder interested in politics would have to resign his traditional office. The document assigns only advisory role to traditional rulers. This role is to be operationalized through the Traditional/Emirate Councils.

The propensity of state governments to exercise excessive control over local governments in the past have deprived them of the free hand needed to function effectively at this level. To act as a bulwark against this trend, the 1976 Reform document provided for the establishment of a Ministry of Local Government in every state of the Federation, where they do not already exist, to serve as a link between the Local Government and the State Government. The document however emphasized that the role of the Ministry of Local Government was essentially to be that of advice, assistance and guidance to local governments, rather than that of excessive control whether in the issuing of directives or requesting information.

These provisions were undoubtedly phenomenal in the annals of the development of local government in Nigeria. Adamolekun appear to capture this phenomenal development when he stated that:

what differentiated the 1976 local government reform from all previous reform exercises in the country is the formal and unambiguous recognition of local government as constituting a distinct level of government with defined boundaries, clearly stated functions and provisions for ensuring satisfactory human and financial resources (Adamolekun, 1987: 46).

\section{Implementation of the 1976 Reform}

In pursuance of the provisions of the Reform, elections were held into the Local Government Councils throughout Nigeria on a no-party basis in December, 1976. For well over two and a half years after the Local Government elections, the reforms were implemented with military administrators still at the helms of affairs at the state and federal levels. During this period, there were allegations by local governments that financial allocation from the Federal Government which was channeled through the State Governments was not reaching them for one reason or the other. Due to the past unimpressive image of local governments, former divisional officers were reluctant to serve in the new local governments as they were skeptical about their prospects in the emergent order.

The Federal Government took appropriate steps to remedy these shortfalls. In the financial sphere, the Federal Government directed all state governments in the country to ensure that financial allocations accruing to local governments are disbursed to them on time. In the sphere of personnel, a well articulated strategy of retaining old staff and attracting new ones as well as the training of new staff was embarked upon in different centres in the country (Ola, 1984:95-96).

Before October 1, 1979, when the military handed over administration of the country to civilians, efforts were made to resolve the problems arising from the implementation of the Reforms as they come. A number of provisions were inserted in the 1979 Constitution to forestall certain problems at the local government level. The effort of the Military which culminated in the 1976 Guidelines for Local Government Reform was particularly phenomenal. For one thing, there emerged for the first time, a national rather than a regional/state approach to the question of Local Government Reform in the country. For another, the document itself was a fundamental breakthrough in the history of local government in Nigeria. 
The emergence of elected councils as a result of the reform after a decade of utilizing hand-picked Sole Administrators and Management Committees to run the affairs of local governments, injected fresh enthusiasm in the affairs of local government in the country. Though more than three decades had elapsed since the Reform, it is obvious that its fundamental features would remain points of reference for future reforms in the country for along time to come.

\section{The Military Phase from 1983-1999: A Return to the 1976 Reform Position}

The effort of the military aimed at putting local government on a sound footing in the country regrettably did not go a long way into the future. The Federal and State Governments during the Second Republic (1979-1983) were nonchalant about implementing legal and constitutional imperatives which would have helped to stabilize the third tier of government in the country.

When on December 31,1983, the Military toppled the civilian Government, one of the primary areas of Public Administration they were dissatisfied and alarmed about was the deplorable state of affairs at the local government level. The dissatisfaction of the military administrators informed their swift action. In January, 1984, the Federal Military Government dissolved all the Management Committees set-up by the Civilian Government and appointed Senior Civil Servants as Sole Administrators in their place. The new local government councils created between 1979 and 1983 were abolished. As a more serious measure towards putting local government on a sound footing again, the Federal Government appointed a 20-Man Committee on May 29, 1984 under the chairmanship of Alhaji Ibrahim Dasuki to review the Local Government system in the country.

In an address to the inaugural meeting of the Committee, the Chief of Staff, Supreme Headquarters, Brigadier Tunde Idiagbon (as he then was) lamented that the civilian administration which they had overthrown had succeeded in making a total mess of all the objectives of the revamped local government system. He stressed that, though, the Federal Military Government has taken certain interim measures, he enjoined the Committee to study the problem in detail and recommend steps to be taken.

The Dasuki Report was submitted in 1985, but the Buhari administration could not take much action on it beore it was overthrown and replaced by the Babandida administration. The Babangida administration appointed the Political Bureau in January 1986 to search for a viable political future for Nigeria, The Political Bureau among other things, endorsed many of the recommendations of the Dasuki Report, including retaining the 301 local government one-tier system of 1976-79.

Acting on the recommendation of the Political Bureau, Government put in place machinery that eliminated the intermediary role of the state governments in the remittance of the Local Government share of the fund from the Federation Account as from 1988. This was enshrined in the 1989, 1989 and 1999 Constitutions. The local government share from the Federation Account was also progressively increased from 10\% to 15\% (1991) and then to 20\% (1992) at the expense of state governments. Similarly, states were mandated to contribute $10 \%$ of their internally generated revenue into the purse of local governments or else have the amount deducted at source from the state allocation from the Federation Account.

The Ministry of Local Government at the state level was abolished in 1988. State governments were required to establish Departments of Local Government in the State Governor's Offices to assist, advice and guide, but not to control, local governments in the performance of their constitutional functions. A similar step taken by the regime was the scrapping of Local Government Service Commissions in all states. The power to recruit, promote and disciple local government staff was first vested in each local government, but later reversed.

Other structural and institutional innovations were introduced. Firstly, the regime sought to align local government machinery with the developments in the bureaucratic instruments of higher levels of government. Probably the most debatable re-organisation was the introduction of the Presidential system of government at the local government level in 1991. The office of the Secretary to the Local Government became political (contrary to the recommendation of the Technical Committee). Heads of departments were redesignated as supervisors. A supervisor could be appointed from either within or outside the elected councilors. In the spirit of the separation of powers obtaining in higher levels, an elected councilor would have to give up his position on being appointed a supervisor. The Chairman and his team of supervisors now constituted the executive arm of government at that level (Oyediran 2001).

Decree No. 23 of 1991 provided for a legislature at the local government level known as the Local Government Council. The geo-political area, hitherto known as the local government council would now be known as the local government area. This legislative assembly at the local government level was to be presided over by the Leader and Deputy Leader, who exercised powers parallel to those of Speaker and Deputy Speaker of a State House of Assembly. 
The procedure of appointment and tenure were similar to what obtained at the state level. The Executive (Chairman, Supervisors and Secretary) were now referred to as the Local Government. The separation of powers provided that local government council performs the roles corresponding to those performed by the legislature at higher levels of government, while the local government did the same in respect of the executive council.

Surprisingly, the military administration that raised alarm over the astronomical increase in the number of local government areas in the country by the deposed civilian government in 1983, and even reiterated this in 1987, created 149 new local government areas in May 1989, 140 additional local government areas in 1991 and 182 local government areas in 1986. This brought the number of local government areas in the country to 774 . There were no futher substantial changes as at May 29, 1999 when the military handed over the rein of political power to an elected civilian government.

\section{The Military as Agents of Modernization: Analytical Deductions}

Analytically speaking, the advent of the Military in Nigeria's political scene has had a great deal of impact on the Local Government system in the country. During the Military Phase prior to the 1976 Reform, what seemed obvious was the absence of any mechanism to ensure that the services rendered by the so called efficiency oriented local administration were responsive to the local feelings. This was because the Military Administration during this period had no orientation towards mass participation or involvement at the local as well as the higher levels of government. The emphasis on efficiency and provision of affordable services at the cost of popular involvement and the adoption of democratic doctrines which hitherto had started to gain ground before the military intervention, led to apathy on the part of the people towards local government affairs. This was very obvious where those appointed as Sole Administrators or as members of Management Committees, as the case may be, were not known to the people or were from a different local government area (Ola, 1978:71-2).

The preference of the Military for efficient administration the expense of the celebrated ideals of democracy required further analysis. While it must be conceded that the military organisational style is essentially authoritarian where adherence to the hierarchical principle is sacrosanct, the issues involved are more than these. For one thing, the military seized power at a time when the fierce political wrangling at the local level had almost paralysed the Local Government system in the country. For another, in many cases, democratic practices or popular involvement was only on paper and not in practice at the local level. This was obvious from the fact that many of the Local Government Councils were during this period being run by Management Committees appointed on partisan basis. Further, the civil war the country went through from 1967 to 1970 had a great deal of devastating effect on the economic life of the country and thus needed urgent rehabilitation. Overwhelmed by all these odds, the Military Administrators were inclined to convert all the three levels of government into efficiency oriented organisations. To some extent at least, the efficiency oriented strategy was dictated by the exigencies of the time (Ola, 1978; Ola \& Tonwe, 2009).

The above line of argument is further buttressed by the fact they the efficiency objective for the military was not an all-time measure. The setting up of the Public Service Review Commission and the acceptance of their recommendations as they relate to local government before the Gowon Administration was toppled in 1975, clearly indicated that the Federal Military Government was ready to make a start towards institutionalizing democratic local government that could fulfill the economic and political roles in their immediate environment as well as the larger political and economic environment.

It was however, the unprecedented 1976 nation wide reform efforts by the Mohammed/Obasanjo Military Administration that illuminated genuine interest and commitment of the Military to the development of viable democratic local government institutions in the country. Their efforts encouraged meaningful participation at the local level. Their decision to support the local governments financially was particularly phenomenal. The effort of the military since 1983 has reinforced the commitment of the military to ensuring that local governments are given the necessary impetus to function effectively as the third tier of government in the country. The decision of the military to abolish the Ministries of Local Governments throughout the country was to invigorate local autonomy. The allocation of revenue accruing from the Federation Account directly to the Local Governments was to forestall the manipulative tendencies of the state governments aimed at hijacking resources meant for local governments. The decision to assign executive powers to the Local Government Chairmen and the separation of the executive arm of local government from the Local Legislative Councils was informed by the need to fully integrate the third tier of government into the presidential system as it operates at the State and Federal levels. Thus for the military, the sphere of local government is one that must always be given prime attention. This was reflected in President Babangida's (1988) statement when he said. 
From our experience, we have realised that local government is the closest to the people. It is also the bedrock of the projected democratic order and is admirably well-placed to tackle and resolve most of the issues and problems that confront our people....We are equally convinced and determined to make the various local governments the prime centres for social and economic development and the real power base of the new democracy.

While the commitment of the military over the years to the task of ensuring that the third tier of government in the country is put on a sound footing is not in doubt, it is perhaps worth-while to ponder over why the military has been able to act as an agent of modernization, so much so that their modernization efforts trickled down to the base of the country's body politic. A ponderous situation such as this does require a critical examination. There are basically two schools of thought, though diametrically opposed to each other regarding the role of Military in developing countries.

The first school of thought portrays the military as a conservative and unprogressive force. This school of thought contends that it is much easier for the military to seize power than to govern as a ruling group. Since the military is not equipped for governance in civil society and most of the countries where the military have seized power they have done a poor job in the task of governance. Even some of the seemingly innovative steps are said to be with ulterior motive. For example, elections at the local level during military regimes are undertaken not on its merit but as a ploy for perpetuating their stay in office by giving the impression that there is plan to eventually disengage from governance at all levels of government. The Babangida era clearly shows that conduct of elections at the local level and even at the state level is not an indication that the military is in the process of disengaging from the political stage (Ferguson, 1987).

Also, it is argued that the widely acknowledged effort of the military to enhance local autonomy is in fact a strategy to further centralize power. The elimination the intermediary role of the state governments in the remittance of the Local Government share of the fund from the Federation Account on the recommendation of the Political Bureau from 1988, the increase in local government share from the Federation Account progressively from 10\% to $15 \%$ (1991) and then to $20 \%$ (1992), and mandatory contribution of $10 \%$ of internally generated revenue of state governments into the coffers of local governments or in default get the amount deducted at source from the state allocation of the Federation Account, were all at the expense of the state governments. With such developments the centre ultimately becomes much more dominant in relation to other levels of government. The federal government, by centralizing power to make local government policies, did not find it difficult to decentralize it to local government without much challenge. The idea of two levels of government - federal and local; that was stongly canvassed during the Political Bureau days (between January 1985 and April 1986), did not help matters for state governments. The aim was to fizzle out the state governments from the political equation. An anti-state government attitude was encouraged by the military in a tactful manner under the Babangida administration. This was not that difficult to achieve because the unpopularity of state governments arising from their repressive tendencies in relation to local government between 1979 and 1983 during civilian rule.

The second school of thought opines that the military is the best organised institution and therefore in the best position to act as an agent of modernization in developing countries. Huntigton $(1957,1968)$ and Pye $(1962)$ support this view point. A third school of thought finds a place at the middle of the continuum of the two schools of thought already mentioned.

A detailed and empirical examination of this school of thought with a view of generalizing is certainly beyond the scope of this paper. In pondering over the consistent commitment of the military in ensuring that Local Governments are put on a sound footing vis-à-vis the higher levels of government, some peculiar traits of the military which have helped to make them an effective modernizing force in the country's body politic can be distilled. The Military itself is a modernized institution. Even in the developed countries, it was during wars or from the military set-up itself that many of the civilian institutional arrangements, ways of thinking and methods of organisation first evolved (Barnett, 1965). Further, military colleges emerged before business schools and it was military schools that blazed the trail in engineering and technology. Even in modern times, many of the technological developments and innovations for peaceful purposes emanated from war research. In a number of the developing countries (including Nigeria) modernization and exposure to Western techniques came first to the military officers and then to other groups in the society. Such influences have equipped the military to respond fairly well to the demands of modernization.

Another important fact is that the military has peculiar organisational characteristics of centralised pattern which put in place a strong leadership. In the Nigerian setting, where the society is not only heterogeneous, but also characterized by cleavages among the numerous ethnic and communal groups, the strength of the military leadership and clear goal definition which are characteristic of military operations have given impetus to the ability of the military to put in place supportive political institutions to diffuse the strains in inter-ethnic and inter-communal relations and ensure effective participation of all the ethnic and communal groups in the country's political process. This manifested in the creation of 12 States from the erstwhile four regions in 1967, 19 States in 1976, 21 States in 1987, 30 States in 1991 and 
36 States by the military. This bifurcation and the concomitant increase in the number of local governments created a framework for the participation of hitherto marginalized ethnic groups in the political process. The introduction of the two -party system during the march towards the third Republic was partly to curb ethnicism.

Also important is the very nature of the army. In this regard, Lucian Pye (1962:78-79) noted that:

\begin{abstract}
the armies by nature are rival institutions in the sense that they are usually required to be tested against one another when the need arises. This makes them alert and also to have the tendency to look beyond their immediate society for better skills to outmatch one another. The civil bureaucracy can, and usually does deal with its domestic problem without much regard for what other bureaucracies in other countries are doing. The solider, however, is constantly called upon to look abroad and compare his organisation with foreign ones. He thus has greater awareness of standards around the globe and a greater sensitivity to the weaknesses of his own society.
\end{abstract}

The way the military in Nigeria attempted a gradual political neutralization of traditional authorities corroborates Pye's observation. From the political perspective it is an illusion to think that the military institutional arrangement is nonpolitical. In this regard, Pye (1962:82-3) observed that:

\begin{abstract}
one important feature of acculturation within the army is that it usually provides some form of training citizenship and nationalism. Recruits are required to think about the new world in which they must identify with a larger political self. In a way, the army experience tends to be a political experience. Even if recruits are not given explicit training in political matters, they are likely to learn that events in their society are determined by human decisions and not just by chance and fate.
\end{abstract}

These attributes may have stood in good stead for the military to play modernizing role in Nigeria. It took a number of radical measures for the political reconstitution of the resurgent nation. These measures took the shape of introduction of the presidential system of government; political re-organisation of the nation into 36 States and a Federal Capital Territory; restructuring of the local government system into 744 local government areas; introduction of a tripartite federal system; political neutralization of traditional authorities; amongst others.

\title{
9. Concluding Comments
}

The military no doubt brought about momentous changes in the local government system in Nigeria. The country expects that these innovations will have a lasting impact on the restoration of health to the country's body politic. The revival and entrenchment of democracy in the country's body politic is very much needed now. Out of the 53 years of the postindependence period, the nation had experienced democratic rule for only 24 years (1960-1966), (1979-1983) and (1999-2013), that too in a perverted form. Now, after a mopping up and cleansing up exercise for 30 years, the nation's citizenry should be allowed, without any extraneous hindrance, to enjoy a democratic system in a full bloom form, being nourished by a vibrant local democracy. This is essential because, despite the virtues of the military as modernizers, martial rule can not be a substitute for democratic self rule. The military should be quick enough to recognize that over the years, all the virtues of discipline and sincerity of purpose which endeared them to the people in the past have fizzled out. To contend that the people are now weary of the military and basically see them as opportunists is to say the least.

Sustained democracy that is nourished by a sound local government system is also needed for providing a conducive environment for evolving a new political culture which subserves the need of a modernizing federal polity in a new nation. So far, this opportunity has been denied due to short-lived and distorted democratic phases and three decades of military rule. In such condition, Nigeria could only have affective orientation which is manifested in feelings of attachment to or rejection of the political system, its personnel and performance. Further, the long rule by the military could only bring about a subject political culture which is evident from the high degree of orientation of output aspects of political system and low degree of orientation towards the input and active participation aspects. What a modernizing federal polity such as Nigeria is expected to strive to evolve is evaluative orientation which involves the application of value standards by the citizenry in making judgement and forming opinion about political objects and events; and a participant political culture which involves orientation of the citizenry to both the input and output aspects of the political system. It is hoped that the military will realise this national need and give way for all time so that democracy can entrench itself in the country's political system. 


\section{References}

Adamolekun, Ladipo (1979). The Idea of Local Government as Third Level of Government in L. Adamolekun and L. Rowland (eds), The New Local Government System in Nigeria, Heinemann Press, Ibadan, pp 68-76.

Ademoyega, Adewale. (1981). Why We Struck, The Story of the First Nigerian Coup. Ibadan: Evans Brothers.

Bako, A. (1969). Zaria: Policy Broadcast, June 15.

Barnett, C. (1961). The Education of the Military Elites, Journal of Contemporary History, 2(4), 125-138.

Federal Republic of Nigeria, Guidelines for Local Government (1976). Lagos: Federal Government Press.

Federal Republic of Nigeria, Report of the Political Bureau (1987). Abuja: Directorate for Social Mobilisation.

Ferguson G. (1987). Coup d'etat: A practical manual, Dorset: Arms and Armour Press Limited.

First, Ruth. 1970. The Barrel of a Gun, Political Power in Africa and the Coup d'Etat. London: Penguin Books Ltd.

Gowon A. (1970). Unity, Stability and Progress, Lagos: Federal Ministry of Information.

Humes, S. (1973). Governing for Local Development, Paper Presented to the Canadian Political Science Association Conference, Montreal: Carlon Press.

Huntington, S. P. (1957). The Soldier and the State: The Theory and Politics of Civil-Military Relations. Cambridge, MA: Harvard University Press.

Huntington, S. P. (1968). Political Order in Changing Societies, New Haven: Yale University.

Lockard, D. (1968). Local Government. In Sill, D.L. (ed.), International Encyclopedia of the Social Sciences, London and New York: Macmillan and Free Press, pp 453-470.

Miners, N.J. (1971). The Nigerian Army: 1956-1966, London: Methuen and Company Ltd.

Odetola, T.O. (1982). Military Regimes and Development: A Comparative Analysis of African Societies, London: George Allen \& Urwin.

Ola, R.O.F. (1984), Local Administration in Nigeria, London: Kegan Paul International.

Ola, R.O.F. \& Tonwe, D.A. (2009), Local Administration and Local Government in Nigeria, Lagos: Amfitop Books.

Orewa, G.O. \& Adewumi, J.S. (1983). Local Government in Nigeria: The Changing Scene, Benin City: Ethiope Publishing Corporation.

Oyediran, O. (2001). Local Government as a Third Tier of Government in Nigeria: The 1976 Local Government Reforms and After in Elaigwu J.I. and Akindele R.A. (eds), Foundations of Nigerian Federalism (1960-1995), Ibadan: University Press, 77-90.

Pye, L.W. (1962), Armies in the Process of Political Modernization. In Johnson, J.J. (ed.): The Role of the Military in Underdevelopment Countries, New Jersey: Princeton University Press.

Siollun, Max. (2009). Oil, Politics and Violence: Nigeria's Military Coup Culture (1966-1976). New York: Algora Publishing.

Summerhayes, G. V. (1969). The Changing Relations between the Native Authorities and the New Northern States' Administration, IleIfe: University of Ife Press.

West Africa Magazine (WAM), (1971), Lagos: West African Publishers.

Wit, D. (1961). A Comparative Study of Local Government and Administration, Bangkok: Houghton Publishers. 